UC-940 amd UC-902

Issued: June 1995

Radionuclide Concentrations in Vegetation at

Radioactive-Waste Disposal Area G during the 1994 Growing Season

P. R. Fresquez*

J. B. Biggs*

K. D. Bennett ${ }^{+}$ 


\title{
RADIONUCLIDE CONCENTRATIONS IN VEGETATION AT RADIOACTIVE- WASTE DISPOSAL AREA G DURING THE 1994 GROWING SEASON
}

by

\author{
P. R. Fresquez, J.B. Biggs, and K.D. Bennett
}

\begin{abstract}
Overstory (pinon pine) and understory (grass and forb) vegetation samples were collected within and around selected points at Area G-a low-level radioactive solid-waste disposal facility at Los Alamos National Laboratory - for the analysis of tritium $\left({ }^{3} \mathrm{H}\right)$, strontium $\left({ }^{90} \mathrm{Sr}\right)$, plutonium $\left({ }^{238} \mathrm{Pu}\right.$ and $\left.{ }^{239} \mathrm{Pu}\right)$, cesium $\left({ }^{137} \mathrm{Cs}\right)$, americium ( ${ }^{241} \mathrm{Am}$ ), and total uranium. In general, most vegetation samples collected within and around Area $G$ contained radionuclide levels in higher concentrations than vegetation collected from background areas. Tritium, in particular, was detected as high as $5,800 \mathrm{pCi} / \mathrm{mL}$ in overstory vegetation collected outside the fence just west of the tritium shafts; this suggests that tritium is migrating from this waste repository through subsurface pathways. Also, understory vegetation collected north of the transuranic (TRU) pads (outside the fence of Area G) contained the highest values of ${ }^{90} \mathrm{Sr}$, ${ }^{238} \mathrm{Pu},{ }^{239} \mathrm{Pu},{ }^{137} \mathrm{Cs}$, and ${ }^{241} \mathrm{Am}$, and may be a result of surface holding, storage, or disposal activities.
\end{abstract}

\section{INTRODUCTION}

Solid radioactive wastes have been buried by Los Alamos National Laboratory (LANL) since the early 1940's (Purtymun et al. 1980). Area G-a 25.5 hectare (63 acre), low-level radioactive management and disposal area located on the east end of Mesa del Buey at TA54-was established in 1957 and, at present, is the Laboratory's primary radioactive-solidwaste burial and storage site (Soholt 1990) (Figure 1). In general, wastes (contaminated equipment, paper, plastics, clothing, building materials, soils, and process wastes) are placed in either pits, trenches, or shafts and then covered with fill material (Hanson et al. 1980). Tritium, uranium, plutonium, and a variety of fission and activation products are the main isotopes in waste materials deposited at Area G (U.S. DOE 1979).

As part of the Environmental Surveillance Program at LANL, air, soil, sediments, veg- 


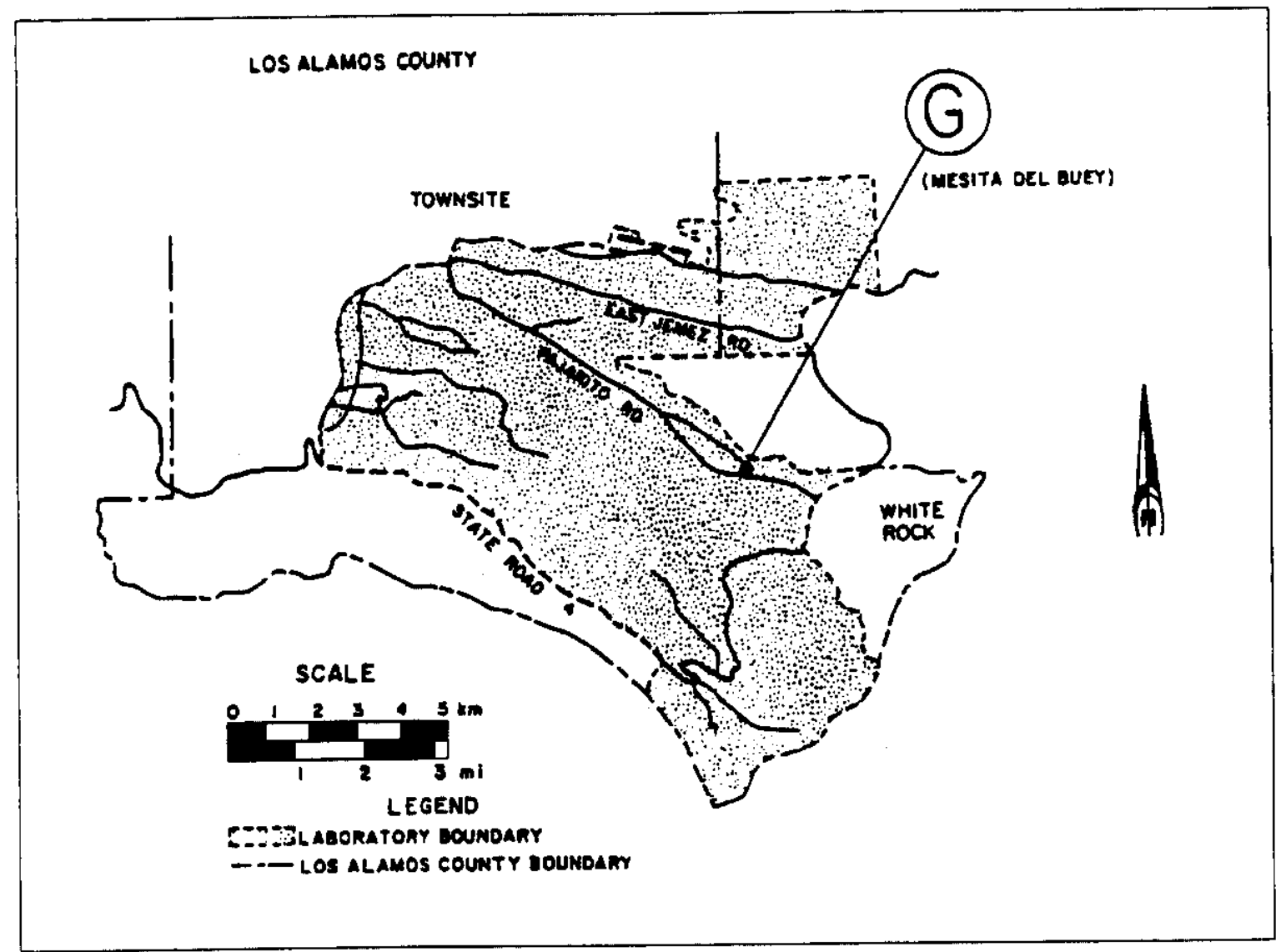

Fig. 1. Area G location within Los Alamos National Laboratory.

etation, biota, bees, and honey are collected on an annual basis from radioactive disposal site Area $G$ to monitor and assess the site's impact on the surrounding community (Environmental Protection Group 1994). One important component of this program is the assessment of vegetation growing within and around Area $G$ for radiological contamination; the uptake of isotopes by vegetation, for example, may give some insight into surface (Hanson et al. 1980) and subsurface (Wenzel et al. 1987) contaminant pathways to man from waste disposal areas. Trees, in particular, have been shown to be excellent indicators of subterranean tritium migration out of low-level radioactive-waste disposal sites (Rickard and Kirby 1987).

The objective of this study was to determine the concentrations of selected radionuclides in overstory and understory vegetation within (inside the fence) and around (outside the fence) Area $G$. These data were compared with radionuclide concentrations in vegetation collected from a regional background location upwind of the Laboratory. 


\section{METHODS}

On September 13, 1994, the Ecological Studies Team of the Environmental Assessments and Resource Evaluations Group (ESH-20) collected 12 vegetation samples from six areas within and around Area $G$ at TA-54. The six sampling areas were located (1) south of the tritium shafts just outside the fence, (2) west of the tritium shafts just outside the fence, (3) east side of the new waste pit inside the fence, (4) north of the TRU pads just outside the fence, (5) west side of the TRU pad, and (6) east side of the TRU pad (Figure 2). Background samples were also collected approximately four miles southeast and upwind of the Laboratory.

At each site, vegetation samples were collected from either pinon pine (Pinus edulis, [overstory]) or grasses and forbs (understory) or both. Pinon pine are the most typical overstory tree of the surrounding forest (Tierney and Foxx 1982). Overstory samples consisted of tree-shoot-tips approximately 1 to $2 \mathrm{in}$. in length at the 4 - to 5 - $\mathrm{ft}$ height. Understory samples consisted of five grass and forb (top growth) subsamples from the center and corners of a $30-$ by $30-\mathrm{ft}$ area. The pinon pine trees acted as the center of the square.

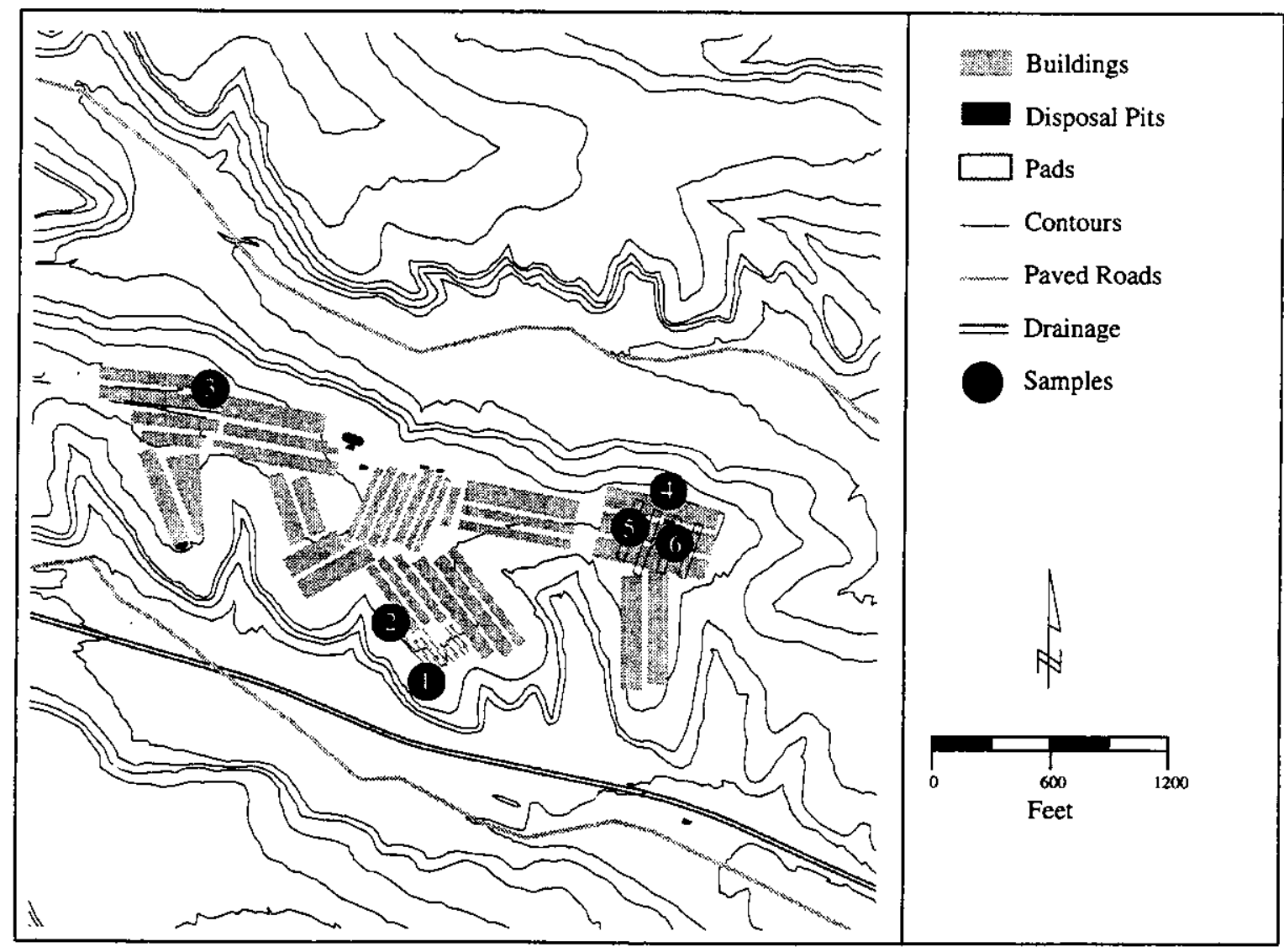

Fig. 2. Locations of vegetation samples collected at Area $G$. 
All samples were collected with plastic gloves and clean shears, and placed in labeled Ziploc plastic bags. Each sample consisted of 2 to $3 \mathrm{lb}$ of composited material. Samples were double-bagged and transported to the Laboratory in locked ice chests. At the Laboratory, a subsample from each bag was heated to collect distillate (water) for tritium analysis. The rest of the sample was placed in 1-L glass beakers and ashed at $500 \mathrm{lC}$ for $120 \mathrm{~h}$. The sample ash was pulverized and homogenized, transferred to labeled $500-\mathrm{mL}$ poly bottles, and submitted with the distillate (water) samples under full chain-of-custody to the Environmental Chemistry Group (CST-9) for the analysis of tritium, ${ }^{90} \mathrm{Sr},{ }^{238} \mathrm{Pu},{ }^{239} \mathrm{Pu},{ }^{137} \mathrm{Cs}$, ${ }^{241} \mathrm{Am}$, and total uranium. All methods of radiochemical analysis have been described previously (Salazar 1984). Results were reported in $\mathrm{pCi} / \mathrm{mL}$ (of tissue moisture) for tritium and $\mathrm{mg}$ or $\mathrm{pCi}$ per gram of ash for all other isotopes; results in grams of ash are usually two to four orders of magnitude higher than live (wet) weight.

\section{RESULTS}

Results of the analysis are presented in Table 1. In general, most of the radiological concentrations in overstory and understory vegetation collected from within and around Area $\mathrm{G}$ were higher than upper-limit background values. The upper-limit background concentration is defined as the analytical result plus two sigma.

Tritium ranged in concentration from 2.5 to $5,800 \mathrm{pCi} / \mathrm{mL}$ and from 35.6 to $952.5 \mathrm{pCi} /$ $\mathrm{mL}$ in overstory and understory samples collected from Area $\mathrm{G}$, respectively. The highest tritium concentration was detected in an overstory sample collected just outside the fence west of the tritium shafts; this suggests some subsurface migration of tritium out of Area G. Tritium has been reported to be moving from the tritium shafts in the vapor phase along the contact points of two ash flows (penetrated by the tritium shafts), open joints, and open pores in the tuff matrix (Purtymun 1973). In 1985, from 2,200 to $4,800 \mathrm{pCi} / \mathrm{mL}$ in overstory vegetation was reported in this same tritium shaft area (Jacobson 1992). Other past data showing tritium levels around Area $G$ are presented in Table 2.

Concentrations of ${ }^{90} \mathrm{Sr}$ ranged from 2.0 to $11.2 \mathrm{pCi} / \mathrm{g}$ ash in vegetation collected from within and around Area G. Most samples were around two times the background levels for ${ }^{90} \mathrm{Sr}$; however, there was one sample, a grass and forb composite sample collected just north of the fence line from the TRU pads, that contained ${ }^{90} \mathrm{Sr}$ levels over five times the background level.

Total uranium concentrations in vegetation collected from Area $G$ ranged from 0.89 to 
Table 1. Radionuclide concentrations in vegetation collected from Area G (TA-54) during the 1994 growing season.

\begin{tabular}{|c|c|c|c|c|c|c|c|c|c|c|c|}
\hline \multicolumn{2}{|c|}{$\begin{array}{l}\text { Sites } \\
\text { Radioactive Waste Disposal Area G }\end{array}$} & $\left.{ }^{3} \mathbf{H} / \mathbf{m L}\right)^{a}$ & \multicolumn{2}{|c|}{$\begin{array}{c}{ }^{90} \mathrm{Sr} \\
(\mathrm{pCV} g \text { ash })\end{array}$} & \multicolumn{2}{|c|}{$\begin{array}{l}\text { Uranium } \\
\text { ( } \mu \mathrm{g} / \mathrm{g} \text { ash) }\end{array}$} & $\begin{array}{c}{ }^{238} \mathrm{Pu} \\
(\mathrm{pCi} / \mathrm{g} \text { ash })\end{array}$ & $\begin{array}{c}{ }^{239,240} \mathrm{Pu} \\
(\mathrm{pCi} / \mathrm{g} \text { ash })\end{array}$ & \multicolumn{2}{|c|}{$\begin{array}{c}{ }^{137} \mathrm{Cs} \\
\text { (pCi/g ash) }\end{array}$} & $\begin{array}{c}{ }^{241} \mathrm{Am} \\
(\mathrm{pCi} / \mathrm{g} \text { ash) }\end{array}$ \\
\hline \multicolumn{12}{|c|}{ \#1 Tritium Shafts (south of the shafts just outside the fence) } \\
\hline Overstory & 119.1 & $(7.2)^{7}$ & 4.0 & $(0.6)$ & 1.19 & $(0.26)$ & $0.003(0.002)$ & $0.007(0.002)$ & 0.22 & $(0.22)$ & $0.004(0.002)$ \\
\hline Understory & 201.1 & $(10.0)$ & 3.5 & $(0.4)$ & 2.05 & $(0.58)$ & $0.023(0.006)$ & $0.021(0.004)$ & 0.21 & $(0.18)$ & $0.010(0.006)$ \\
\hline \multicolumn{12}{|c|}{ \#2 Tritium Shafts (west of the shafts just outside the fence) } \\
\hline Overstory & $5,800.0$ & $(200.0)$ & 5.0 & $(0.6)$ & 1.31 & $(0.52)$ & $0.003(0.001)$ & $0.006(0.002)$ & 0.25 & $(0.26)$ & $0.003(0.002)$ \\
\hline Understory & 328.0 & $(13.8)$ & 5.4 & $(0.8)$ & 1.58 & $(0.32)$ & $0.006(0.002)$ & $0.013(0.004)$ & 0.36 & $(0.24)$ & $0.008(0.002)$ \\
\hline \multicolumn{12}{|c|}{$\# 3$ Waste Pits (east of the new pit inside the fence) } \\
\hline Overstory & 9.2 & $(1.0)$ & 2.6 & $(0.4)$ & 3.29 & $(1.72)$ & $0.028(0.006)$ & $0.024(0.006)$ & 0.15 & $(0.16)$ & $0.006(0.002)$ \\
\hline Understory & 38.2 & (3.8) & 4.2 & (0.6) & 0.89 & $(0.18)$ & $0.022(0.004)$ & $0.013(0.004)$ & 0.16 & $(0.16)$ & $0.003(0.002)$ \\
\hline \multicolumn{12}{|c|}{ \#4 TRU Pads (north of pads just outside the fence) } \\
\hline Overstory & 2.5 & $(1.0)$ & 6.0 & $(0.8)$ & 0.94 & $(0.18)$ & $0.044(0.008)$ & $0.012(0.004)$ & 0.05 & $(0.06)$ & $0.008(0.002)$ \\
\hline Understory & 35.6 & (3.6) & 11.2 & (1.4) & 1.62 & $(0.92)$ & $0.452(0.040)$ & $0.153(0.016)$ & 0.39 & $(0.24)$ & $0.090(0.010)$ \\
\hline \multicolumn{12}{|c|}{ \#5 TRU Pads (west side of the pad) } \\
\hline Understory & 177.3 & (9.2) & 3.3 & $(0.4)$ & 1.23 & $(0.24)$ & $0.012(0.004)$ & $0.014(0.004)$ & 0.07 & $(0.08)$ & $0.008(0.002)$ \\
\hline \multicolumn{12}{|c|}{ \#6 TRU Pads (east side of the pad) } \\
\hline Understory & 952.5 & $(30.6)$ & 2.0 & $(0.4)$ & 1.72 & $(0.34)$ & $0.003(0.002)$ & $0.009(0.001)$ & 0.14 & $(0.14)$ & $0.006(0.002)$ \\
\hline \multicolumn{12}{|c|}{ Regional (Background) } \\
\hline Overstogy & 1.2 & $(0.6)$ & 2.0 & $(0.4)$ & 0.33 & $(0.06)$ & $0.000(0.002)$ & $0.000(0.002)$ & 0.10 & $(0.10)$ & $0.002(0.002)$ \\
\hline OSRSRL & 1.8 & & 2.4 & & 0.39 & & 0.002 & 0.002 & 0.20 & & 0.004 \\
\hline Understgry & 1.1 & $(0.8)$ & 1.8 & $(0.4)$ & 0.36 & $(0.08)$ & $0.002(0.002)$ & $0.001 \quad(0.002)$ & 0.13 & $(0.14)$ & $0.002(0.002)$ \\
\hline USRSRL $^{\text {a }}$ & 1.9 & & 2.2 & & 0.44 & & 0.004 & 0.003 & 0.27 & & 0.004 \\
\hline \multicolumn{12}{|c|}{$\begin{array}{l}\text { a mL of tissue moisture. } \\
\text { ( } \mid 2 \text { counting uncertainty). } \\
\text { d OSRSRL=Overstory regional statistical reference level (i.e., the upper-limit background concentration based on the mean }+2 \text { counting uncertainties). } \\
\text { USRSRL=Understory regional statistical reference level (i.e., the upper-limit background concentration based on the mean }+2 \text { counting uncertainties). }\end{array}$} \\
\hline
\end{tabular}


Table 2. Comparison of past and present ${ }^{3} \mathrm{H}$ and ${ }^{239} \mathrm{Pu}$ data in vegetation collected at similiar sites within and around Area G.

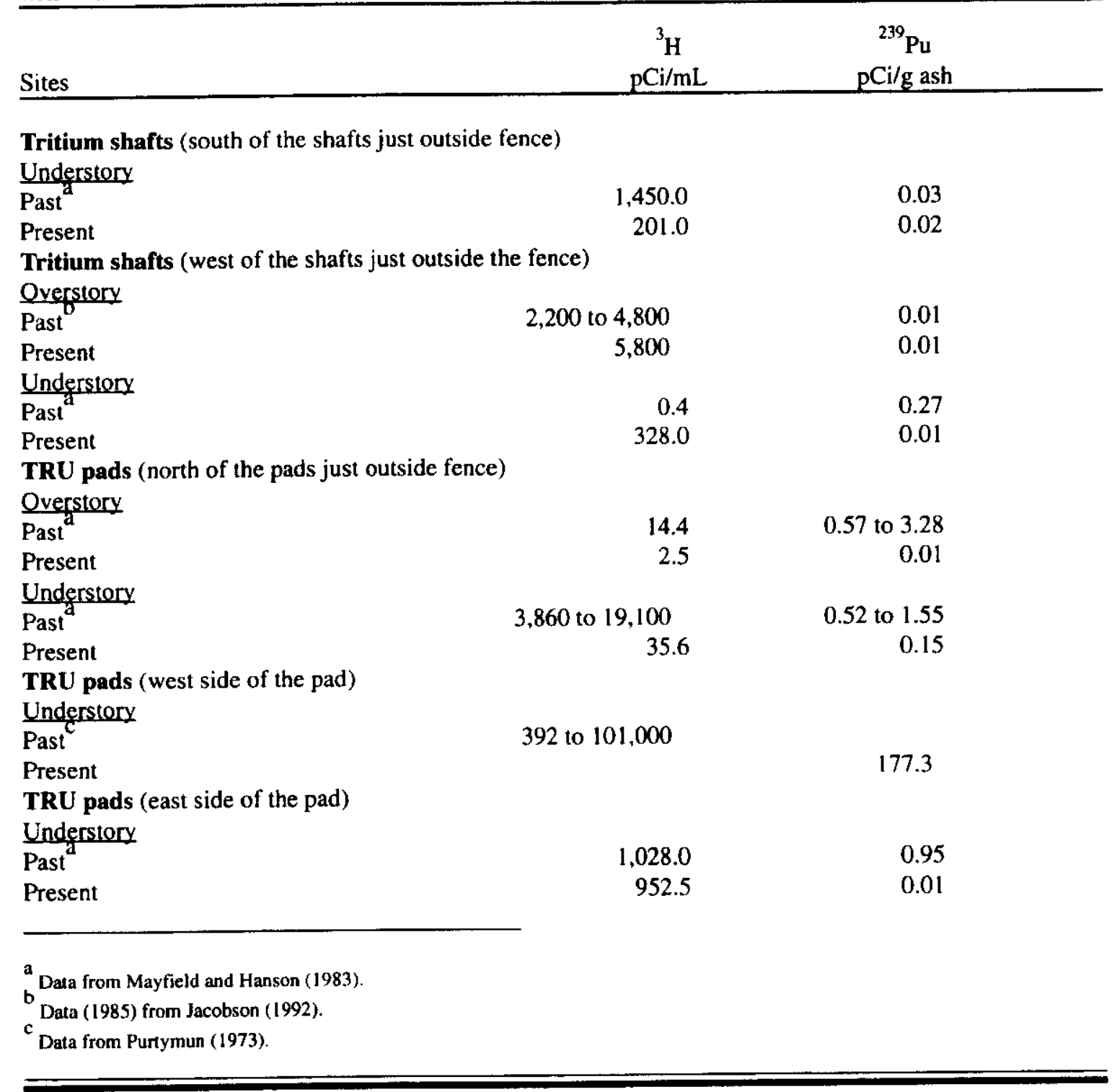

$3.29 \mathrm{mg} / \mathrm{g}$ ash. Most vegetation samples collected over Area G contained approximately five times more uranium than background samples. The highest amount of uranium was detected in pinon trees growing near the new waste pit. In 1980, total uranium in vegetation collected within and around Area $\mathrm{G}$ ranged from 0.09 to $1.0 \mathrm{mg} / \mathrm{g}$ ash (Mayfield and Hanson 1983).

Concentrations of both ${ }^{238} \mathrm{Pu}$ and ${ }^{239} \mathrm{Pu}$ were highest in understory vegetation samples collected north of TRU pads (outside the fence). Values of ${ }^{238} \mathrm{Pu}$ and ${ }^{239} \mathrm{Pu}$ collected north of the TRU pads measured 0.452 and $0.153 \mathrm{pCi} / \mathrm{g}$ ash, respectively, which are approximately 
113 and 51 times background. Overstory and understory vegetation collected from this general location north of the TRU pads in 1980 contained ${ }^{239} \mathrm{Pu}$ at concentrations ranging from 0.57 to 3.28 and from 0.52 to $1.55 \mathrm{pCi} / \mathrm{g}$ ash, respectively (Table 2) (Mayfield and Hanson 1983). Mayfjeld and Hanson (1993) attributed the higher ${ }^{239} \mathrm{Pu}$ levels in understory vegetation collected from Area G, compared with vegetation collected from background areas, to occasional spills during disposal operations or to surface storage and holding practices.

Cesium-137 ranged in concentration from 0.07 to $0.39 \mathrm{pCi} / \mathrm{g}$ ash in vegetation collected from Area $G$. With the exception of two understory samples-one collected west of the tritium shafts and the other collected outside the fence north of the TRU pads-most vegetation samples were within or very close to background levels. Similarly, most ${ }^{241} \mathrm{Am}$ concentrations in vegetation samples collected at Area $G$ were within or just above background ${ }^{241} \mathrm{Am}$ levels. The highest ${ }^{241} \mathrm{Am}$ value was detected in understory vegetation collected just outside the fence-line north of the TRU pads.

\section{REFERENCES}

Environmental Protection Group, "Environmental Surveillance at Los Alamos During 1992," Los Alamos National Laboratory report LA-12764-ENV (July 1994).

Hanson, R.W., D.L. Mayfield, and L.J. Walker, "Interim Environmental Surveillance Plan for LASL Radioactive Waste Areas," Los Alamos Scientific Laboratory report LA-UR80-3110 (October 1980).

Jacobson, K., "Soil and Vegetation Sampling at TA-54, Area G," Los Alamos National Laboratory memorandum EM-8:92-3003, to Johnny Harper (September 1992).

Mayfield, D.L., and W.R. Hanson, "Surface Reconnaissance Through 1980 for Radioactivity at Radioactive Waste Disposal Area G at the Los Alamos National Laboratory," Los Alamos National Laboratory report LA-9656-MS (March 1983).

Purtymun, W.D., "Underground Movement of Tritium from Solid-Waste Storage Shafts," Los Alamos Scientific Laboratory report LA-5286-MS (May 1973).

Purtymun, W.D., M.A. Rogers, and M.L. Wheeler, "Radiochemical Analyses of Samples 
from Beneath a Solid Radioactive Waste Disposal Pit at Los Alamos, New Mexico," Los Alamos Scientific Laboratory report LA-8422-MS (June 1980).

Rickard, W.H. and L.J. Kirby, "Trees as Indicators of Subterranean Water Flow From a Retired Radioactive Waste Disposal Site," Health Physics 52(2):201-206, 1987.

Soholt, L.F., "Environmental Surveillance of Low-Level Radioactive-Waste-Management Areas at Los Alamos During 1987," Los Alamos National Laboratory report LA-UR-903283 (November 1990).

Tierney, G.D. and T.S. Foxx, "Floristic Composition and Plant Succession on NearSurface Radioactive Waste Disposal Facilities in the Los Alamos National Laboratory," Los Alamos National Laboratory report LA-9219-MS (March 1982).

U.S. DOE, "Final Environmental Impact Statement: Los Alamos Scientific Laboratory Site, Los Alamos, New Mexico," U.S. Department of Energy report DOE/EIS-0018 (1979).

Wenzel, W.J., T.S. Foxx, A.F. Gallegos, G. Tierney, and J.C. Rodgers, "Cesium-137, Plutonium-239/240, Total Uranium, and Scandium in Trees and Shrubs Growing in Transuranic Waste at Area B," Los Alamos National Laboratory report LA-11126-MS (November 1987). 
This report has been reproduced directly from the best available copy.

It is available to DOE and DOE contractors from the Office of Scientific and Technical Information,

P.O. Box 62,

Oak Ridge, TN 37831.

Prices are available from

(615) 576-8401.

It is available to the public from the National Technical Information Service,

US Department of Commerce,

5285 Port Royal Rd.

Springfield, VA 22161. 


\section{Los Alamos \\ NATIONAL LABOAATORY \\ Los Alamos, New Mexico 87545}


FECENED

\section{JUL 181995}

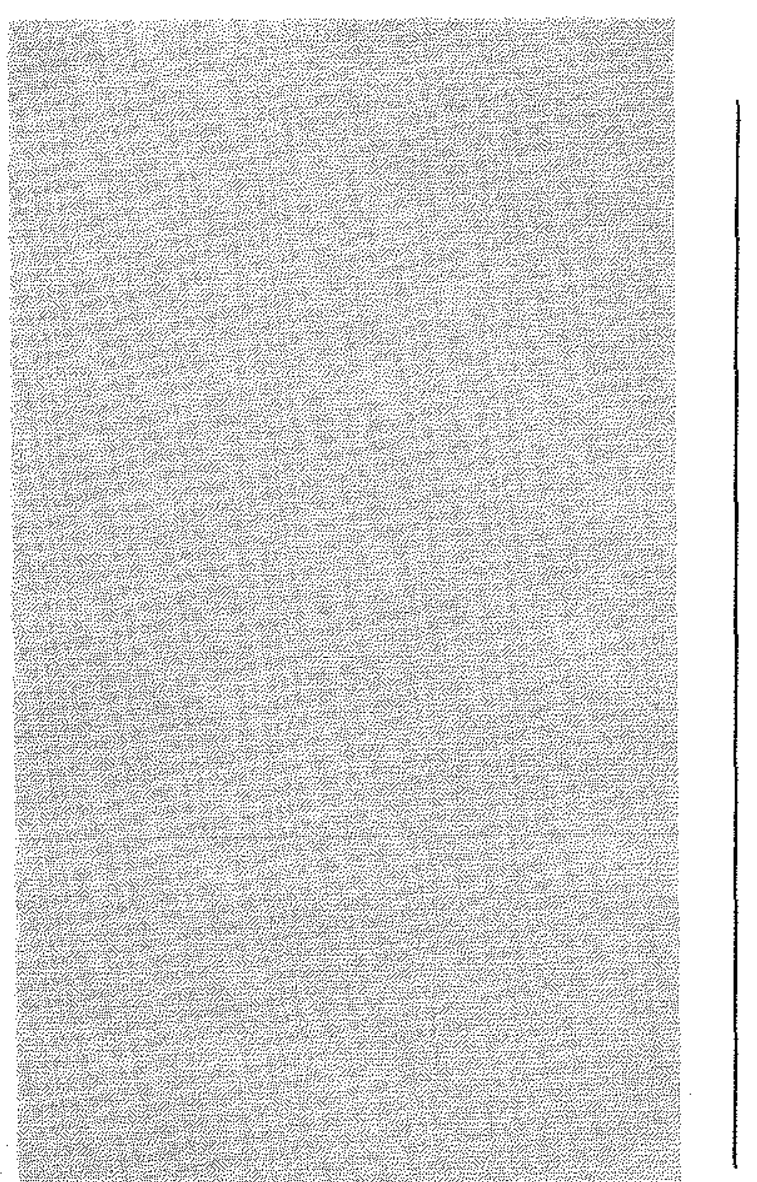

\section{OSTI}

Radionuclide Concentrations in Vegetation at Radioactive-Waste Disposal Area G during the 1994 Growing Season

\section{Los Alamos


Edited by Amy Ferguson, Group CIC-1

An Affirmative Action/Equal Opportunity Employer

This report was prepared as an account of work sponsored by an agency of the

United States Government. Neither The Regents of the University of California, the

United States Government nor any agency thereof, nor any of their employees, makes any warranty, express or implied, or assumes any legal liability or responsibility for the accuracy, completeness, or usefulness of any information, apparalus, product, or process disclosed, or represents that its use would not infringe privately owned rights. Reference herein to any specific commercial product, process, or service by trade name, trademark, manufacturer, or otherwise, does not necessarily constitute or imply its endorsement, recommendation, or favoring by The Regents of the University of California, the United States Government, or any agency thereof. The views and opinions of authors expressed herein do not necessarily state or reflect those of The Regents of the University of Califormia, the United States Government, or any agency thereof. 